\title{
Carcass and non-carcass component characteristics of lambs fed with cassava wastewater dregs in replacement of corn ${ }^{1}$
}

\section{Características de carcaça e componentes não-carcaça de cordeiros alimentados com borra de manipueira em substituição ao milho}

\author{
Daniel Barros Cardoso ${ }^{2 *}$; Robson Magno Liberal Véras 3 ; \\ Francisco Fernando Ramos de Carvalho ${ }^{4}$; André Luiz Rodrigues Magalhães ${ }^{3}$; \\ Gustavo Araújo de Vasconcelos ${ }^{2}$; Stela Antas Urbano ${ }^{5}$; Gerlison de Mélo Fonsêca ${ }^{6}$; \\ Marciella Thais Dino de Freitas ${ }^{6}$
}

\begin{abstract}
The objective was to evaluate the effect of the substitution $(0,33,66$ and $100 \%)$ of corn by cassava wastewater dregs on carcass characteristics and non-carcass components of crossbred Santa Inês lambs. Forty male sheep, uncastrated with an average initial body weight of $20 \pm 1.87 \mathrm{~kg}$ and five months of age, were used. These were housed in individual pens in a randomized block design with four treatments and ten repetitions and slaughtered after 70 days of confinement. Quadratic effect $(P<0.05)$ was observed for the empty body weight (EBW), hot carcass weight (HCW) and cold carcass weight (CCW) and carcass compactness index (CCI), with maximum points of 36.14, 19.45, 20.20 and $0.31 \mathrm{~kg} \mathrm{~cm}^{-1}$ for the replacement level of corn for cassava wastewater dregs, 50.0, 53.84, 54.04 and $45.45 \%$ respectively. There was also an effect $(P<0.05)$ on the weights of the rumen and "Buchada", with maximum points of 0.909 and $6.25 \mathrm{~kg}$ per replacement level, 49.11 and $51.29 \%$ respectively. As for retail cuts, only the efficiency of the leg was altered $(P<0.05)$, having a linear increase while the other variables were not affected. Cassava wastewater dregs can be used in full as an alternative food in the diet of feedlot lambs without harming the main carcass characteristics and non-carcass components.
\end{abstract}

Key words: Alternative food. Meat. Organs. Cassava. Sheep.

\section{Resumo}

Objetivou-se avaliar o efeito da substituição $(0,33,66$ e 100\%) do milho pela borra de manipueira sobre as características de carcaça e componentes não-carcaça de cordeiros mestiços Santa Inês. Foram utilizados quarenta ovinos machos não castrados, com peso corporal inicial médio de $20 \pm 1,87 \mathrm{~kg}$ e cinco meses de idade. Estes foram confinados em baias individuais, em delineamento em blocos ao acaso, com quatro tratamentos e dez repetições, e abatidos após 70 dias de confinamento. Efeito

${ }^{1}$ Parte da dissertação do primeiro autor, projeto financiado pelo CNPq/INSA.

2 Discentes do Curso de Mestrado do Programa de Pós-Graduação em Zootecnia, Universidade Federal Rural de Pernambuco, UFRPE, Recife, PE, Brasil. E-mail: danbarre@hotmail.com; gustavo.zootecnia@yahoo.com.br

3 Profs. Drs., Unidade Acadêmica de Garanhuns, UFRPE, Garanhuns, PE, Brasil. E-mail: robson.veras@ufrpe.br; andre30036@, gmail.com

${ }^{4}$ Prof. Dr., Departamento de Zootecnia, UFRPE, Recife, PE, Brasil. E-mail: francisco.rcarvalho@ufrpe.br

5 Bolsista do Programa Nacional de Pós-Doutorado, PNPD, Universidade Federal do Rio Grande do Norte, UFRN, Centro de Tecnologia, Departamento de Agropecuária, Lagoa Nova, Natal, RN, Brasil. E-mail: stela_antas@yahoo.com.br

${ }^{6}$ Discentes do Curso de Graduação em Medicina Veterinária, UFRPE, Recife, PE, Brasil. E-mail: gerlisonmelo@hotmail.com; marcidinno@hotmail.com

* Author for correspondence 
quadrático $(\mathrm{p}<0,05)$ foi observado para o peso do corpo vazio (PCV), peso de carcaça quente (PCQ) e fria (PCF) e o índice de compacidade da carcaça (ICC), as mesmas apresentaram pontos de máxima de 36,$14 ; 19,45 ; 20,20$ e $0,31 \mathrm{~kg} \mathrm{~cm}^{-1}$ ao nível de substituição do milho pela borra de manipueira de 50,$0 ; 53,84 ; 54,04$ e $45,45 \%$, respectivamente. Também houve efeito $(\mathrm{p}<0,05)$ sobre os pesos do rúmen e da buchada, com ponto de máxima de 0,909 e 6,25 kg ao nível de substituição de 49,11 e 51,29\%, respectivamente. Quanto aos cortes comerciais, apenas o rendimento da perna foi alterado $(p<0,05)$ apresentando efeito linear crescente. Enquanto as demais variáveis não foram afetadas. A borra de manipueira pode ser utilizada de forma integral como alternativa alimentar na dieta de cordeiros em confinamento, sem prejudicar as principais características da carcaça e os componentes não-carcaça.

Palavras-chave: Alimentos alternativos. Carne. Órgãos. Mandioca. Ovinos.

\section{Introduction}

The sheep cutting industry has been growing in some regions of Brazil, especially as an important activity for national livestock. In this activity, confinement is being considered as a viable alternative by allowing an intensification of animal production that is associated with reduced time to produce housing in term of the quantity and quality required by the market and accelerated returns on the capital employed (BARROS et al., 2015; REGO et al., 2015). In this production system, the fact is that conventional food concentrates, such as corn and soybean meal, are crucial for the rise in costs of confinement (XENOFONTE et al., 2009). They may represent about $70 \%$ of production costs because these ingredients have greatly varying prices throughout the year due to exports and use in food and in the diet of poultry and pork.

Agro-industrial waste stands out as an alternative for feeding ruminants in order to lessen production costs by replacing traditional ingredients, such as corn and soybeans. Also, the use of such waste in times of food shortages is common. Another important factor is to give a correct destination to these materials in order to reduce the impacts to the environment when disposed of improperly.

Cassava (Manihot esculenta Crantz) is a root widely consumed in Brazil. In its processing, for the production of flour or starch, various wastes, such as bark, between shell scrapings, bran and cassava wastewater, are generated (FERREIRA, 2013). Cassava wastewater is a yellowish liquid obtained during the pressing of cassava for the production of flour or starch. This waste is a great potential polluter, due to its high rate of biochemical oxygen demand (BOD) and high concentration of hydrocyanic acid, which can cause significant environmental impacts, contaminating rivers and watercourses (SOUZA et al., 2014).

In the production of cassava flour and in starch industries, cassava wastewater is usually place in large tanks or cisterns. During this liquid storage, decanting of its solid parts occurs, thus generating another residue, known in some regions as "cassava wastewater dregs", an introduced paste form with higher dry matter content and a high concentration of starch as compared to cassava.

Some studies were conducted to evaluate cassava wastewater for feed ruminants (ALMEIDA et al., 2009; SANTOS FILHO et al., 2015; URBANO et al., 2015). However, there is a paucity of studies assessing the effects of cassava wastewater dregs for animal feed since this material exhibits very different nutritional characteristics from cassava wastewater. Due to its nutritional characteristics, this agro-industrial residue can be used in ruminant feed as an energy ingredient, replacing traditional ingredients, such as corn.

According to Cezar and Souza (2010), a correct assessment of housing is essential to meet the consumer market for meat that is in increasing demand and is increasingly demanding about quality. Therefore, the assessment of carcass yield and the proportion of commercial cuts, among other 
factors, are important parameters in determining profitability ratios in the production chain of lamb (ALVES et al., 2013). Similarly, the proper conformation indicates proportional development in different anatomical regions that integrate it, so the best conformations are achieved when parts of higher value are well pronounced (ZUNDT et al., 2003). Calculating the carcass compactness indices and the leg indicates the relationship between muscle mass and fat and length and serves to evaluate the amount of material deposited per unit length, representing the evaluation of the conformation (CUNHA et al., 2002).

The objective was to evaluate the effects of replacing corn by cassava wastewater dregs on the characteristics of the housing and non-housing sheep feedlot components.

\section{Material and Methods}

This research was previously approved by the Ethics Committee on Animal Use in Research (CEUA-UFRPE) with protocol number (23082.007295/2013), following the recommendations of the National Council for
Animal Experiment Control (National Council for Control of Animal Experimentation, CONCEA) for the protection of animals used for scientific purposes.

The experiment was conducted in the Feed Evaluation Laboratory for Small Ruminants III of the Department of Animal Science of the Universidade Federal Rural de Pernambuco (UFRPE), Recife, Brazil. Forty-eight lambs, noncastrated crossbred Santa Inês, with five months of age and average initial body weight of $20 \pm$ $1.87 \mathrm{~kg}$, were confined for 70 days in individual stalls $(1.0 \mathrm{~m} \times 1.2 \mathrm{~m})$, provided with a feeder and drinker. The animals were initially identified and treated against ecto and endo-parasites and previously adapted to the management and facilities for 30 days. The animals were fed ad libitum (at 8:00 and 15:00 hours) allowing their plenty of about $10 \%$ of the offered feed and had unrestricted access to water. The ingredients used in the experimental diets were Tifton-85 hay, spineless cactus (Cochenillifera Nopalea (L.) Salm Dyck cv Miúda), soybean meal, ground corn, cassava wastewater dregs, mineral salt, salt and urea (Table 1).

Table 1. Chemical composition of feed used in the diet.

\begin{tabular}{lcccccccccc}
\hline \multicolumn{1}{c}{ Ingredients $\left(\mathrm{g} \mathrm{kg}^{-1}\right)$} & $\mathrm{DM}^{1}$ & OM & CP & Ash & EE & NDFap & NFC & Starch & Calcium & Phosphorus \\
\hline Corn & 887.4 & 984.4 & 76.3 & 15.6 & 46.1 & 167.3 & 697.2 & 63.4 & 0.03 & 0.25 \\
Cassava wastewater dregs & 390.6 & 929.9 & 77.9 & 70.0 & 43.2 & 26.4 & 782.4 & 69.7 & - & - \\
Soybean meal & 881.4 & 927.8 & 478.7 & 72.7 & 18.1 & 137.0 & 296.2 & 8.2 & 0.34 & 0.58 \\
Tifton hay & 890.0 & 919.9 & 83.5 & 80.1 & 15.8 & 791.3 & 82.3 & - & 0.42 & 0.17 \\
Cactus pear & 128.6 & 852.6 & 52.0 & 147.3 & 7.4 & 291.9 & 520.5 & 13.7 & 2.5 & 0.24 \\
Urea + Ammonium sulphate & 990.0 & 991.0 & 2630.0 & - & - & - & - & - & - & - \\
Sodium chloride & 990.0 & 107.1 & - & - & - & - & - & - & - & - \\
Mineral mix & 990.0 & 10.0 & - & - & - & - & - & - & - & - \\
\hline
\end{tabular}

${ }^{1} \mathrm{~g}$ kg-1natural matter; DM dry matter, OM organic matter, CP crude protein, EE ether extract, NDFap neutral detergent fibre corrected for ash and protein, NFC non-fibre carbohydrates.

${ }^{2}$ Assurance levels provided by the manufacturer: calcium $=140 \mathrm{~g}$, phosphorus $=70 \mathrm{~g}$, magnesium $=1320 \mathrm{mg}$, iron $=2200 \mathrm{mg}$, cobalto $=140 \mathrm{mg}$, manganese $=3690 \mathrm{mg}$, zinc $=4700 \mathrm{mg}$, iodine $=61 \mathrm{mg}$, selenium $=45 \mathrm{mg}$, sulphur $=12 \mathrm{~g}$, sodium $=148 \mathrm{~g}$, and fluorine $=700 \mathrm{mg}$. 
Tifton hay was triturated in a forage machine with an $8 \mathrm{~mm}$ sieve screen, and the forage was cut into a palm disintegrating machine. Cassava wastewater dregs were acquired in flour mills located in the city of Glória do Goitá, Pernambuco, Brazil and transported to the site of the experiment. Here, the cassava wastewater dregs were stored in plastic drums of $200 \mathrm{~L}$ and covered with mesh to keep out insects.

The treatments consisted of the replacement $(0$, 33,66 and $100 \%$ ) of corn by cassava wastewater dregs (Table 2). Diets were formulated based on NRC (2007) to meet weight gains of $200 \mathrm{~g} \mathrm{day}^{-1}$. The experimental diets were provided in the form of complete mixing.

Weekly samples were collected from food and orts, which were placed in pre-labelled plastic bags and stored in a freezer $\left(-18^{\circ} \mathrm{C}\right)$. Subsequently, the samples were predried in an oven with forced ventilation at $55{ }^{\circ} \mathrm{C}$ and ground in a mill with sieves of $1 \mathrm{~mm}$ diameter to perform the chemical composition analysis, as the contents of dry matter $(\mathrm{DM})$, ash, crude protein (CP), ether extract (EE), neutral detergent fibre (NDF) and acid detergent fibre (ADF), determined in accordance with methods INCT-CA G-003/1; M-001/1; N-001/1; G-005/1; F-002/1 and F-004/1 respectively, according to the methods described by Detmann et al. (2012).

To estimate the total digestible nutrients (TDN), a digestibility trial was carried out. Samples of $1.0 \mathrm{~g}$ of the concentrate and $0.5 \mathrm{~g}$ of hay, faeces and diet remains were incubated in a TNT bag (nonwoven fabric) for 288 hours in the rumen of a fistulated adult male buffalo. The remaining material was subjected to incubation with an acid detergent digestion residue, which was considered indigestible acid detergent fibre (iADF), according to INCT-CA method F-011/1 and according to the methodology Detmann et al. (2012).

Table 2. Quantity of ingredients and chemical composition of the experimental diets

\begin{tabular}{|c|c|c|c|c|}
\hline \multirow{2}{*}{ Ingredients ( $\left.\mathrm{g} \mathrm{kg}^{-1} \mathrm{DM}\right)$} & \multicolumn{4}{|c|}{ Replacement levels (\%) } \\
\hline & 0 & 33 & 66 & 100 \\
\hline Corn & 300.0 & 200.0 & 100.0 & 0.0 \\
\hline Cassava wastewater dregs & 0.0 & 97.4 & 194.7 & 292.0 \\
\hline Soybean meal & 143.0 & 143.0 & 143.0 & 143.0 \\
\hline Tifton hay & 250.0 & 250.0 & 250.0 & 250.0 \\
\hline Cactus pear & 293.0 & 293.0 & 293.0 & 293.0 \\
\hline Urea + Ammonium sulphate & 0.0 & 2.6 & 5.3 & 8.0 \\
\hline Sodium chloride & 5.0 & 5.0 & 5.0 & 5.0 \\
\hline \multirow[t]{2}{*}{ Mineral mix } & 9.0 & 9.0 & 9.0 & 9.0 \\
\hline & \multicolumn{4}{|c|}{ Chemical composition } \\
\hline Dry matter * & 325.3 & 311.2 & 298.3 & 286.4 \\
\hline Crude protein ${ }^{1}$ & 137.0 & 142.3 & 147.8 & 153.3 \\
\hline Ether extract ${ }^{1}$ & 27.2 & 23.7 & 20.2 & 16.7 \\
\hline Neutral detergent fibre ${ }_{a \mathrm{a}}{ }^{1}$ & 327.1 & 316.3 & 305.5 & 294.7 \\
\hline Acid detergent fibre ${ }^{1}$ & 152.7 & 150.3 & 147.9 & 145.5 \\
\hline Non-fibre carbohydrates ${ }^{1}$ & 424.6 & 431.0 & 437.4 & 443.8 \\
\hline $\operatorname{Starch}^{1}$ & 242.3 & 246.7 & 251.1 & 255.5 \\
\hline Total digestible nutrients ${ }^{1}$ & 603.0 & 624.8 & 631.1 & 634.7 \\
\hline Metabolizable energy $\left(\mathrm{kcal} \mathrm{kg}^{-1} \mathrm{DM}\right)$ & 2180 & 2259 & 2281 & 2295 \\
\hline Calcium $^{1}$ & 9.8 & 9.8 & 9.7 & 9.7 \\
\hline Phosphorus ${ }^{1}$ & 2.7 & 2.5 & 2.2 & 2.0 \\
\hline
\end{tabular}

* $\mathrm{g} \mathrm{kg}^{-1}$ natural matter; ${ }^{1} \mathrm{~g} \mathrm{~kg}^{-1}$ dry matter. 
To estimate the total carbohydrates (TC), the equation proposed by Sniffen et al. (1992) was used: TC $(\mathrm{g} / \mathrm{kg})=1000-(\mathrm{CP}+\mathrm{EE}+\mathrm{ash})$ and nonfibre carbohydrates (NFC); we used the method described by Hall (2000) in which NFC $(\mathrm{g} / \mathrm{kg})=$ 1000 - [(CP - urea - derived CP + urea $)+$ NDFap $+\mathrm{EE}+\mathrm{ash}]$ where $\mathrm{CP}=$ crude protein, $\mathrm{EE}=$ ether extract, NDFap $=$ neutral detergent fibre corrected for ash and protein.

To estimate the total digestible nutrients (TDN), the equation described by Weiss (1999) was adopted, in which TDN $(\%)=(\% \mathrm{CPd}+$ $\%$ NDFapd $+\%$ NFCd $+(\%$ EEd $\times 2.25)-7(\mathrm{CPd}$, digestible crude protein; NDFapd, digestible neutral detergent fibre corrected to protein and ash; NFCd, digestible non-fibrous carbohydrate; EEd, digestible ether extract). To calculate the metabolizable energy (ME), digestible energy (DE) was initially calculated as the product of TDN and the factor 4,409/100, considering the concentration of MS of $82 \%$ of ED.

For the results of the dry matter intake (DMI), total digestible nutrients intake (TNDI) of neutral detergent fibre (NDF) and digestibility of dry matter (DDM) and average daily gain (ADG), we used the results and discussion as obtained by Vasconcelos (2013).

After 70 days of confinement, the animals were subjected to a fasting diet and water solids for 16 hours. Immediately before slaughter, they were weighed to obtain the body weight at slaughter (BWS). The animals were stunned for concussion with a penetrating captive bolt pistol (Ctrade $\AA$, Tec 10 PP) driven by an exploding cartridge, followed by bleeding of the carotid artery and jugular vein section (BRASIL, 1997).

After skinning and gutting, the head and feet were removed and the hot carcass weight (HCW) recorded. Then, the carcasses were put in cold storage, with an average temperature of $4^{\circ} \mathrm{C}$, and kept for 24 hours suspended on hooks by the tendon of the gastrocnemius muscle. They were then weighed, getting the cold carcass weight (CCW), according to the methodology of Cezar and Sousa (2007). Also, carcass $\mathrm{pH}$ readings were taken at 0 hours and 24 hours pos mortem from the Semimembranosus muscle with the aid of a $\mathrm{pH}$ meter/insertion thermometer (Testo 205).

The organs [tongue, trachea, lungs, liver, heart, diaphragm, spleen, pancreas, gall bladder, kidneys and thymus], reproductive system [testicles, penis, bladder, and glands], the viscera [oesophagus, rumen, reticulum, omasum, abomasum, small intestine and large intestine] and the by-products [blood, head, feet, skin, internal fat and perirenal fat] were weighed to measure the non-carcass components. The emptied viscera was washed and re-weighed according to the scheme proposed by Silva Sobrinho and Gonzaga Neto (2001).

"Buchada" constituents were considered as blood, liver, kidneys, lungs, spleen, tongue, heart, omentum, rumen, reticulum, omasum and small intestine (MEDEIROS et al., 2008). "Panelada" were considered "Buchada" constituents increased by the head and legs (CLEMENTINO et al., 2007).

The gastrointestinal tract (GIT) was weighed filled then emptied and weighed to determine the empty body weight (EBW), and the biological or true yield $[\mathrm{BY}=(\mathrm{CCW} / \mathrm{EBW}) \times 100]$ were also calculated for hot carcass yield $[\mathrm{HCY}=(\mathrm{HCW} /$ $\mathrm{BWS}) \times 100]$, cold carcass yield $[\mathrm{CCY}=(\mathrm{CCW} /$ BWS) $\times 100$ ] and weight loss by cooling [LC $=(\mathrm{HCW}-\mathrm{CCW}) / \mathrm{HCW} \times 100]$ according to methodology of Cezar and Sousa (2007).

Subjective evaluations were carried for conformation, finishing, renal-pelvic fat and morphometric measurements of carcasses according to the methodology proposed by Cezar and Sousa (2007). The carcass compactness index (CCI) and the leg compactness index (LCI) were also calculated using the following formulas: [CCI $\left.(\mathrm{kg} \mathrm{cm})^{-1}\right)=(\mathrm{CCW} /$ internal length carcass $\left.)\right]$ and [LCI $\left(\mathrm{cm} \mathrm{cm}^{-1}\right)=$ hind width/leg length, second (CEZAR; SOUSA, 2007)]. Later the tail was 
removed, and the carcass was divided sagittally and into six anatomical regions composed of the neck, shoulder, rib, saw, loin and leg. Their yields were calculated in relation to half reconstituted housing, according to the methodology proposed by Cezar and Sousa (2007).

In the left half carcass a cross-section was made between the 12th and 13th ribs to measure the Longissimus muscle area (LMA), and the muscle contour was traced on a plastic sheet transparency for the subsequent determination of the area in a digital planimetric machine $\left(\mathrm{HAFF}{ }^{\circledR}\right.$, DIGIPLAN model) (COSTA et al., 2012). Also in the L. dorsi, with the aid of a digital calliper, the rib fat thickness (RFT) was measured, obtained at a distance of $3 / 4$ from the medial side of the second muscle, the methodology Cezar and Sousa (2007).

The experimental design was a randomized block, formed according to the initial weight of the animals, according to the following model $\mathrm{Yij}=\mu$ $+\mathrm{Ti}+\mathrm{bj}+$ eij where $\mathrm{Y} \mathrm{ij}=$ the observed value of the dependent variable, $\mu=$ the overall average, the treatment effect $=(i=1$ to 4$), b j=$ the effect of block $\mathrm{j}(\mathrm{j}=1$ to 4$)$ and eij $=$ the experimental error. Data were submitted to variance and regression analysis, considering the level of 5\% probability for the type I error, using procedures PROC GLM and PROC REG of statistical package SAS (2002).

\section{Results and Discussion}

Replacing corn by cassava wastewater dregs influenced $(P<0.05)$ average daily gain $(\mathrm{ADG})$, empty body weight (EBW) and hot (HCW) and cold carcass weight $(\mathrm{CCW})$, with quadratic behaviour (Table 3).

The ADG variables EBW, $\mathrm{HCW}$ and $\mathrm{CCW}$ showed maximum values of $295 \mathrm{~g}^{\text {day }}{ }^{-1}, 36.14$, 19.45 , and $20.20 \mathrm{~kg}$ to the level of replacing of corn,
49.96, 50.0, 53.84 and 54.04\% respectively. There not being significant changes to DMI and TDNI by replacing the quadratic behaviour of ADG, may have been due to a greater availability of nutrients for tissue deposition on the substrate, depending on the type of starch and starch content present in the cassava wastewater dregs. According to McAllister et al. (1993), the structural carbohydrate present in the grain and protein matrix of starch granules is the main factor behind the existing digestibility differences between sources of starch. According to Zeoula et al. (1999), cassava has a higher degradability of starch when compared to corn due to lack of a pericarp protein matrix and the higher amylopectin content of the starch granules. Consequently, we see the influence of ADG, EBW, HCW and CCW (Table 3).

Body weight at slaughter (PCA) and the contents of the gastrointestinal tract (GIT) were not affected $(P>0.05)$ by the replacement of corn by cassava wastewater dregs, with average values of 37.91 and $4.75 \mathrm{~kg}$ respectively (Table 3 ). There was also no influence on hot carcass yield (HCY), cold carcass yield (CCY) and biological yield (BY), with average values of $49.54,48.0$ and $56.63 \%$ respectively (Table 3 ). Values of hot carcass yield (HCY) (47.97\%) were observed by FurushoGarcia et al. (2010), who worked with Santa Inês pure bred sheep in confinement and slaughtered at $38.2 \mathrm{~kg}$. And lower values, observed $41.79 \%$ and $40.14 \%$ for HCY and CCY respectively, were found by Faria et al. (2011), who evaluated different ways of processing cassava hulls in diets of sheep slaughtered at $30.72 \mathrm{~kg}$. Santos Filho et al. (2015) found HCY values of 53.6, 53.1, 53.4, 50.8 and $50.9 \%$ with the inclusion $0 ; 25 ; 50 ; 75$ and $100 \%$ of cassava wastewater (liquid form) replacing corn respectively in the diet of Santa Ines sheep slaughtered at 30.7, 31.3, 29.4, 29.9 and $26.5 \mathrm{~kg}$ of body weight respectively. 
Table 3. Intake, average daily gain and carcass characteristics of lambs fed with cassava wastewater dregs in replacement for corn.

\begin{tabular}{|c|c|c|c|c|c|c|c|}
\hline \multirow{2}{*}{ Variables } & \multicolumn{5}{|c|}{ Replacement levels (\%) } & \multirow{2}{*}{$\mathrm{Eq}$} & \multirow[b]{2}{*}{ P-value } \\
\hline & 0 & 33 & 66 & 100 & SEM & & \\
\hline DMI $\left(\text { g day }^{-1}\right)^{*}$ & 1254.90 & 1419.05 & 1309.86 & 1275.07 & 27.539 & $\hat{\mathrm{Y}}=1314.72$ & 0.149 \\
\hline TDNI $\left(\mathrm{g} \mathrm{day}^{-1}\right)^{*}$ & 752.82 & 827.81 & 824.74 & 795.99 & 19.365 & $\hat{\mathrm{Y}}=800.34$ & 0.505 \\
\hline $\operatorname{NDFI}\left(\mathrm{g} \mathrm{day}^{-1}\right)^{*}$ & 382.00 & 394.86 & 352.09 & 312.49 & 8.365 & 1 & 0.001 \\
\hline $\operatorname{DMD}\left(\mathrm{g} \mathrm{day}^{-1}\right)^{*}$ & 601.33 & 608.88 & 635.44 & 634.12 & 2.654 & 2 & 0.025 \\
\hline $\mathrm{ADG}\left(\mathrm{g} \mathrm{day}^{-1}\right)^{*}$ & 242.60 & 283.00 & 255.20 & 252.10 & 0.005 & 3 & 0.036 \\
\hline BWS (kg) & 36.62 & 39.53 & 37.72 & 37.81 & 0.532 & $\hat{Y}=37.91$ & 0.070 \\
\hline EBW (kg) & 31.86 & 34.97 & 33.12 & 32.77 & 0.493 & 4 & 0.026 \\
\hline GIT (kg) & 4.73 & 4.55 & 4.59 & 5.03 & 0.107 & $\hat{\mathrm{Y}}=4.75$ & 0.367 \\
\hline HCW (kg) & 17.97 & 19.75 & 18.90 & 18.60 & 0.301 & 5 & 0.041 \\
\hline $\mathrm{CCW}(\mathrm{kg})$ & 17.37 & 19.20 & 18.28 & 18.02 & 0.293 & 6 & 0.028 \\
\hline $\operatorname{HCY}(\%)$ & 49.05 & 49.95 & 50.02 & 49.17 & 0.237 & $\hat{Y}=49.54$ & 0.332 \\
\hline $\operatorname{CCY}(\%)$ & 47.43 & 48.55 & 48.39 & 47.64 & 0.227 & $\hat{Y}=48.00$ & 0.221 \\
\hline BY (\%) & 56.40 & 56.44 & 57.02 & 56.72 & 0.215 & $\hat{Y}=56.63$ & 0.735 \\
\hline LC (\%) & 3.32 & 3.16 & 3.26 & 3.11 & 0.100 & $\hat{\mathrm{Y}}=3.21$ & 0.883 \\
\hline RFT (mm) & 1.53 & 1.34 & 1.63 & 1.60 & 0.073 & $\hat{Y}=1.53$ & 0.379 \\
\hline LMA $\left(\mathrm{cm}^{2}\right)$ & 10.66 & 11.22 & 10.67 & 11.09 & 0.164 & $\hat{Y}=10.91$ & 0.566 \\
\hline $\mathrm{pH}$ (0 hours) & 6.81 & 6.84 & 6.86 & 6.78 & 0.022 & $\hat{Y}=6.93$ & 0.683 \\
\hline pH (24 hours) & 5.65 & 5.73 & 5.74 & 5.74 & 0.021 & $\hat{\mathrm{Y}}=5.71$ & 0.297 \\
\hline \multicolumn{8}{|c|}{ Regression equation } \\
\hline TDNI $\left(\text { g day }^{-1}\right)^{*}$ & \multicolumn{5}{|c|}{${ }^{1} \hat{Y}=385.07+0.399 X-0.0115 X^{2}$} & & \\
\hline $\operatorname{DMD}\left(\mathrm{g} \mathrm{day}^{-1}\right)^{*}$ & \multicolumn{5}{|c|}{${ }^{2} \hat{Y}=589.76+0.462 X$} & & \\
\hline $\operatorname{ADG}\left(\mathrm{g} \mathrm{day}^{-1}\right)^{*}$ & \multicolumn{5}{|c|}{${ }^{3} \hat{Y}=0.247+0.0009784 X-0.00000979 X^{2}$} & & \\
\hline EBW $(\mathrm{kg})$ & \multicolumn{5}{|c|}{${ }^{4} \hat{Y}=32.18+0.0800 \mathrm{X}-0.0008 \mathrm{X}^{2}$} & & \\
\hline $\mathrm{HCW}(\mathrm{kg})$ & \multicolumn{5}{|c|}{${ }^{5} \hat{Y}=18.13+0.04954 \mathrm{X}-0.00046 \mathrm{X}^{2}$} & & \\
\hline $\mathrm{CCW}(\mathrm{kg})$ & \multicolumn{5}{|c|}{${ }^{6} \hat{Y}=17.54+0.04972 X-0.00046 X^{2}$} & & \\
\hline
\end{tabular}

DMI $=$ dry matter intake; TDNI $=$ total digestible nutrient intake; NDFI $=$ neutral detergent fiber intake; DMD $=$ dry matter digestibility; $\mathrm{ADG}=$ average daily gain; $\mathrm{BWS}=$ body weight at slaughter; $\mathrm{EBW}=$ empty body weight; $\mathrm{GIT}$ = gastrointestinal tract; $\mathrm{HCW}=$ hot carcass weight, $\mathrm{CCW}=$ cold carcass weight; $\mathrm{HCY}=$ hot carcass yield; $\mathrm{CCY}=$ cold carcass yield; $\mathrm{BY}=$ biological yield; $\mathrm{LC}=$ loss by cooling; $\mathrm{RFT}=$ rib fat thickness; $\mathrm{LMA}=$ Longissimus muscle area; $\mathrm{SEM}=$ standard error of the mean; $\mathrm{Eq}=$ equation; $\mathrm{X}=$ level of cassava wastewater dregs in replacement for corn. * Vasconcelos (2013).

The loss by cooling (LC) was not influenced $(P>0.05)$ by the replacement of corn by cassava wastewater dregs (Table 3). It was within the range proposed by Martins et al. (2000), ranging between 1 and $7 \%$. The absence of the influence of diets on CL, showed consistent results with RFT, which also did not change, with an average value of $1.53 \mathrm{~mm}$ (Table 3). This has the function of protecting against moisture losses during cooling. Urano et al. (2006) found an average of $1.52 \mathrm{~mm}$ for RTF in Santa Ines lambs with a body slaughter weight of $37.7 \mathrm{~kg}$, a body weight close to that of our study. RTF protects against moisture losses during cooling.

The low value found for RTF can be related to the containment time being 70 days, the slaughter of the animals occurring before the fat initiated a greater deposition of fat cover on the housing. Gerrard and Grant (2006) stated that development in body adipose tissue is later, developing just after the peak of muscle growth. Moreover, tropical 
breeds of sheep, such as Santa Inês sheep, have the characteristic of depositing internal fat in the omental, mesentery and perirenal region, working with energy reserves to be mobilized during times of food shortage (MEDEIROS et al., 2008). Thus, in these breeds, subcutaneous fat deposition occurs late.

There was no effect $(P>0.05)$ the substitution of corn by cassava wastewater dregs on Longissimus muscle area (LMA), averaging $10.91 \mathrm{~cm}^{2}$ (Table 3). According to Hashimoto et al. (2012), the LMA determined in the loin (Longissimus dorsi) is considered as a representative measure of the muscularity of carcasses and is used as a parameter for the classification and evaluation of quality and performance. Thus, the results for LMA can be considered satisfactory, indicating good muscularity of the carcasses.
The $\mathrm{pH}$ of carcasses at 0 and 24 hours was not affected $(P>0.05)$ by the replacement (Table 3$)$. Silva Sobrinho et al. (2005) reported that the value of final $\mathrm{pH}$ of lambs ranged from 5.5 to 5.8 , i.e, the $\mathrm{pH}$ observed at 24 hours is normal. This observation is important, since $\mathrm{pH}$ decline pos mortem has a significant impact on the qualitative characteristics of meat (HOPKINS et al., 2011).

There was no influence of the replacement $(P>0.05)$ on the weight of cold half-carcasses (WCHC) and the weights of meat cuts, neck, shoulder, rib, saw, loin and leg (Table 4). This similarity in weights of cuts reinforces the law of anatomical harmony (BOCCARD; DUMONT, 1960). According to these authors, for carcasses with similar weights and quantities of fat, almost all body regions are in similar proportions, whatever the conformation genotype considered.

Table 4. Weights and yields of meat cuts of lambs fed with cassava wastewater dregs in replacement for corn.

\begin{tabular}{|c|c|c|c|c|c|c|c|}
\hline \multirow{2}{*}{ Variables } & \multicolumn{4}{|c|}{ Replacement levels (\%) } & \multirow[b]{2}{*}{ SEM } & \multirow{2}{*}{$\mathrm{Eq}$} & \multirow[b]{2}{*}{ P-value } \\
\hline & 0 & 33 & 66 & 100 & & & \\
\hline WCHC (kg) & 8.41 & 9.11 & 8.80 & 8.61 & 0.133 & $\hat{\mathrm{Y}}=8.73$ & 0.143 \\
\hline Neck (kg) & 0.955 & 1.094 & 1.022 & 0.994 & 0.021 & $\hat{\mathrm{Y}}=1.016$ & 0.058 \\
\hline Shoulder (kg) & 1.493 & 1.578 & 1.530 & 1.506 & 0.022 & $\hat{\mathrm{Y}}=1.527$ & 0.414 \\
\hline Rib (kg) & 1.324 & 1.471 & 1.385 & 1.357 & 0.026 & $\hat{\mathrm{Y}}=1.384$ & 0.169 \\
\hline Saw (kg) & 1.204 & 1.157 & 1.134 & 1.114 & 0.032 & $\hat{\mathrm{Y}}=1.152$ & 0.760 \\
\hline Loin $(\mathrm{kg})$ & 0.841 & 0.920 & 0.845 & 0.825 & 0.018 & $\hat{\mathrm{Y}}=0.857$ & 0.155 \\
\hline Leg (kg) & 2.598 & 2.897 & 2.881 & 2.815 & 0.051 & $\hat{Y}=2.798$ & 0.064 \\
\hline \multicolumn{8}{|l|}{ Yield (\%) } \\
\hline Neck & 11.39 & 12.00 & 11.62 & 11.56 & 0.174 & $\hat{\mathrm{Y}}=11.64$ & 0.649 \\
\hline Shoulder & 17.80 & 17.33 & 17.38 & 17.49 & 0.131 & $\hat{\mathrm{Y}}=17.50$ & 0.616 \\
\hline Rib & 15.76 & 16.11 & 15.78 & 15.71 & 0.185 & $\hat{\mathrm{Y}}=15.84$ & 0.882 \\
\hline Saw & 14.22 & 12.70 & 12.86 & 12.92 & 0.294 & $\hat{\mathrm{Y}}=13.18$ & 0.245 \\
\hline Loin & 9.97 & 10.07 & 9.63 & 9.56 & 0.116 & $\hat{\mathrm{Y}}=9.81$ & 0.358 \\
\hline Leg & 30.84 & 31.76 & 32.72 & 32.74 & 0.271 & 1 & 0.036 \\
\hline \multicolumn{8}{|c|}{ Regression equation } \\
\hline Leg & ${ }^{1} \hat{\mathrm{Y}}=1$ & +0.040 & & & & & \\
\hline
\end{tabular}

$\mathrm{WCHC}=$ weight of cold half-carcass; $\mathrm{SEM}=$ standard error of the mean; Eq = equation; $\mathrm{X}=$ level of cassava wastewater dregs in replacement for corn. 
With regard to yields from the meat cuts, only the yield of the leg was influenced $(P<0.05)$ by the replacement, presenting an increasing linear behaviour (Table 4). This is an important result since the leg is a region with a higher yield of meat and is one of the most valued portions of the housing. The sum of the yields of shoulder and leg was $49.52 \%$. These results corroborate those reported by Furusho-Garcia et al. (2004), in whose study the shoulder and the shank represented approximately $50 \%$ of the housing, these being the cuts that best predict the total content of the carcass tissues.

There was no effect $(P>0.05)$ of the replacement on the hind width, thoracic width, hind perimeter, internal carcass length, external carcass length, thoracic depth, thoracic perimeter, leg length, leg perimeter or leg compactness index (LCI) (Table 5).

The carcass compactness index (CCI) was influenced quadratically $(P<0.05)$ by the replacement of corn by cassava wastewater dregs (Table 5), with a maximum point of $0.31 \mathrm{~kg} \mathrm{~cm}^{-1}$ to the $51.29 \%$ level of replacement. CCI showed the same behaviour as $\mathrm{CCW}$, as this variable is calculated by the ratio of CCW and internal carcass length. The higher the ICC, the greater deposition of muscle tissue per unit area and the better the quality of the casting is (AMORIM et al., 2008). CCI and LCE showed good results in the present study, indicating a good deposition of muscle tissue per unit length, considering that the animals of this study were crossbred Santa Inês sheep.

Table 5. Carcass morphometric measurements and subjective evaluations of lambs fed with cassava wastewater dregs in replacement for corn.

\begin{tabular}{|c|c|c|c|c|c|c|c|}
\hline \multirow{2}{*}{ Variables } & \multicolumn{4}{|c|}{ Replacement levels (\%) } & & \multirow{2}{*}{$\mathrm{Eq}$} & \multirow[b]{2}{*}{$\mathrm{P}$-value } \\
\hline & 0 & 33 & 66 & 100 & SEM & & \\
\hline Hind width $(\mathrm{cm})$ & 22.44 & 23.27 & 23.30 & 22.84 & 0.205 & $\hat{\mathrm{Y}}=22.96$ & 0.393 \\
\hline Thoracic width $(\mathrm{cm})$ & 22.74 & 23.50 & 22.79 & 22.35 & 0.257 & $\hat{Y}=22.84$ & 0.491 \\
\hline Hind perimeter $(\mathrm{cm})$ & 62.77 & 64.41 & 63.92 & 63.94 & 0.400 & $\hat{Y}=63.76$ & 0.381 \\
\hline Internal carcass length $(\mathrm{cm})$ & 63.98 & 64.03 & 64.12 & 64.60 & 0.342 & $\hat{\mathrm{Y}}=64.18$ & 0.924 \\
\hline External carcass length $(\mathrm{cm})$ & 57.90 & 59.00 & 58.85 & 57.85 & 0.437 & $\hat{\mathrm{Y}}=58.40$ & 0.660 \\
\hline Leg length $(\mathrm{cm})$ & 42.19 & 42.28 & 42.61 & 42.33 & 0.279 & $\hat{Y}=42.35$ & 0.960 \\
\hline Thoracic depth $(\mathrm{cm})$ & 26.95 & 27.65 & 27.20 & 27.25 & 0.214 & $\hat{Y}=27.26$ & 0.683 \\
\hline Thoracic perimeter $(\mathrm{cm})$ & 70.67 & 72.87 & 72.01 & 70.96 & 0.442 & $\hat{\mathrm{Y}}=71.62$ & 0.093 \\
\hline Leg perimeter $(\mathrm{cm})$ & 38.46 & 40.88 & 41.36 & 40.98 & 0.478 & $\hat{\mathrm{Y}}=40.42$ & 0.070 \\
\hline LCI $\left(\mathrm{cm} \mathrm{cm}^{-1}\right)$ & 0.53 & 0.55 & 0.55 & 0.54 & 0.004 & $\hat{\mathrm{Y}}=0.54$ & 0.544 \\
\hline $\mathrm{CCI}\left(\mathrm{kg} \mathrm{cm}^{-1}\right)$ & 0.27 & 0.30 & 0.28 & 0.28 & 0.005 & 1 & 0.018 \\
\hline Conformation (1-5) & 2.6 & 3.0 & 2.9 & 2.7 & 0.084 & $\hat{\mathrm{Y}}=2.82$ & 0.457 \\
\hline Finishing (1-5) & 2.6 & 2.9 & 2.6 & 2.8 & 0.087 & $\hat{\mathrm{Y}}=2.76$ & 0.409 \\
\hline Renal-pelvic fat (1-3) & 2.7 & 2.9 & 2.9 & 2.5 & 0.053 & $\hat{\mathrm{Y}}=2.76$ & 0.052 \\
\hline \multicolumn{8}{|c|}{ Regression equation } \\
\hline $\operatorname{ICP}\left(\mathrm{kg} \mathrm{cm}^{-1}\right)$ & $=0.27$ & 000797 & 0.00000 & & & & \\
\hline
\end{tabular}

$\mathrm{LCI}=$ leg compactness index; CCI = carcass compactness index; SEM = standard error of the mean; Eq = equation; $\mathrm{X}=1 \mathrm{evel}$ of cassava wastewater dregs in replacement for corn. 
Conformation traits, finishing and renal-pelvic fat were not affected $(P>0.05)$ by the diets (Table 5). According to the methodology Cezar and Souza (2010), carcasses can be classified as having reasonably good conformation according to the average finish and perirenal fat and the average overall fat. The carcasses of the animals showed a very uniform development, regardless of the replacement of cassava wastewater dregs.

The weights of the tongue, lungs, trachea, heart, spleen, liver, gallbladder, diaphragm, pancreas, thymus and kidneys were not affected $(P>0.05)$ with the substitution of corn by cassava wastewater dregs (Table 6). Also, the total weight of organs (TWO), as well as relations with BWS and EBW, was not affected by the diets (Table 6).

Table 6. Weights and yields of the organs of lambs fed with cassava wastewater dregs in replacement for corn.

\begin{tabular}{|c|c|c|c|c|c|c|c|}
\hline \multirow{2}{*}{ Variables $(\mathrm{kg})$} & \multicolumn{5}{|c|}{ Replacement levels (\%) } & \multirow{2}{*}{$\mathrm{Eq}$} & \multirow[b]{2}{*}{ P-value } \\
\hline & 0 & 33 & 66 & 100 & SEM & & \\
\hline Tongue & 0.085 & 0.093 & 0.090 & 0.088 & 0.002 & $\hat{Y}=0.089$ & 0.571 \\
\hline Lungs & 0.405 & 0.454 & 0.411 & 0.384 & 0.011 & $\hat{\mathrm{Y}}=0.413$ & 0.158 \\
\hline Trachea & 0.130 & 0.141 & 0.139 & 0.137 & 0.004 & $\hat{\mathrm{Y}}=0.137$ & 0.847 \\
\hline Heart & 0.169 & 0.185 & 0.163 & 0.168 & 0.004 & $\hat{\mathrm{Y}}=0.171$ & 0.228 \\
\hline Spleen & 0.079 & 0.069 & 0.092 & 0.073 & 0.006 & $\hat{Y}=0.078$ & 0.558 \\
\hline Liver & 0.714 & 0.759 & 0.740 & 0.693 & 0.015 & $\hat{Y}=0.726$ & 0.367 \\
\hline Gall bladder & 0.031 & 0.032 & 0.037 & 0.034 & 0.002 & $\hat{\mathrm{Y}}=0.034$ & 0.848 \\
\hline Pancreas & 0.080 & 0.084 & 0.081 & 0.096 & 0.006 & $\hat{\mathrm{Y}}=0.085$ & 0.741 \\
\hline Diaphragm & 0.128 & 0.147 & 0.141 & 0.135 & 0.004 & $\hat{\mathrm{Y}}=0.137$ & 0.299 \\
\hline Reproductive system & 0.490 & 0.557 & 0.538 & 0.545 & 0.022 & $\hat{\mathrm{Y}}=0.533$ & 0.677 \\
\hline Thymus & 0.041 & 0.039 & 0.036 & 0.034 & 0.002 & $\hat{Y}=0.038$ & 0.781 \\
\hline Kidneys & 0.120 & 0.132 & 0.117 & 0.127 & 0.002 & $\hat{Y}=0.124$ & 0.132 \\
\hline TWO & 2.475 & 2.695 & 2.587 & 2.517 & 0.045 & $\hat{\mathrm{Y}}=2.568$ & 0.273 \\
\hline TWO/BWS (\%) & 6.76 & 6.82 & 6.85 & 6.67 & 0.087 & $\hat{\mathrm{Y}}=6.77$ & 0.889 \\
\hline TWO/EBW (\%) & 7.77 & 7.71 & 7.81 & 7.70 & 0.092 & $\hat{\mathrm{Y}}=7.74$ & 0.966 \\
\hline
\end{tabular}

$\mathrm{TWO}=$ total weight of organs; BWS = body weight at slaughter; EBW = empty body weight; SEM = standard error of the mean; $\mathrm{Eq}=$ equation; $\mathrm{X}=$ level of cassava wastewater dregs in replacement for corn.

The weights of organs were probably not affected because DMI and TDNI did not vary with the replacement. Medeiros et al. (2008) observed that an increase in concentrate levels in the diets stimulated the development of the liver and gallbladder on the basis of metabolizable energy content and other nutrients. According to Van Soest (1994), the liver is an important organ, acting on several metabolic processes and actively participating in energy metabolism, that captures about $80 \%$ of propionate passing through the portal system for conversion into glucose.

The diets did not influence $(P>0.05)$ oesophagus, reticulum, omasum, abomasum weights, the weights of the small and large intestines, the total weight of viscera (TWV), the weight of the head, feet, skin, blood and internal fat and perirenal fat or the total weight of the byproducts (Table 7). 
There was a significance $(P<0.05)$ in terms of the weight of the rumen with the replacement (Table 7), having quadratic behaviour with a maximum point of $0.909 \mathrm{~kg}$ at the $45.45 \%$ replacement level. This effect of increased rumen weight may be related to NDF, which showed a quadratic effect with replacement (Table 3). According to Van
Soest (1994), the growth of the reticulum-rumen can be influenced by several factors, including diet, especially in terms of NDF content. Faria et al. (2011), using different ways of processing cassava peel in sheep feed, did not observe changes in the weight of the rumen, reticulum, omasum or abomasum.

Table 7. Weight of empty viscera and by-products of lambs fed with cassava wastewater dregs in replacement for corn.

\begin{tabular}{lccccccc}
\hline \multirow{2}{*}{\multicolumn{1}{c}{ Variables $(\mathrm{kg})$}} & \multicolumn{9}{c}{ Replacement levels (\%) } & \multirow{2}{*}{ Eq } & P-value \\
\cline { 2 - 6 } & 0 & 33 & 66 & 100 & SEM & & 0.393 \\
Oesophagus & 0.062 & 0.065 & 0.064 & 0.057 & 0.002 & $\hat{\mathrm{Y}}=0.062$ & 0.016 \\
Rumen & 0.761 & 0.885 & 0.790 & 0.763 & 0.018 & 1 & 0.016 \\
Reticulum & 0.125 & 0.148 & 0.118 & 0.136 & 0.004 & $\hat{\mathrm{Y}}=0.132$ & 0.097 \\
Omasum & 0.102 & 0.115 & 0.110 & 0.082 & 0.004 & $\hat{\mathrm{Y}}=0.102$ & 0.051 \\
Abomasum & 0.146 & 0.156 & 0.141 & 0.142 & 0.004 & $\hat{\mathrm{Y}}=0.146$ & 0.601 \\
Small intestine & 0.662 & 0.728 & 0.685 & 0.731 & 0.018 & $\hat{\mathrm{Y}}=0.701$ & 0.515 \\
Large intestine & 0.359 & 0.366 & 0.315 & 0.335 & 0.008 & $\hat{\mathrm{Y}}=0.344$ & 0.128 \\
Total weight of viscera & 2.218 & 2.465 & 2.223 & 2.246 & 0.040 & $\hat{\mathrm{Y}}=2.288$ & 0.085 \\
\hline Head & 2.157 & 2.255 & 2.134 & 2.175 & 0.027 & $\hat{\mathrm{Y}}=2.18$ & 0.301 \\
Feet & 1.034 & 1.039 & 1.011 & 0.995 & 0.014 & $\hat{\mathrm{Y}}=1.02$ & 0.657 \\
Skin & 3.130 & 3.185 & 2.973 & 3.009 & 0.067 & $\hat{\mathrm{Y}}=3.07$ & 0.645 \\
Blood & 1.575 & 1.630 & 1.643 & 1.626 & 0.040 & $\hat{\mathrm{Y}}=1.61$ & 0.928 \\
Internal fat & 0.134 & 0.150 & 0.120 & 0.121 & 0.009 & $\hat{\mathrm{Y}}=0.130$ & 0.693 \\
Perirenal fat & 0.426 & 0.543 & 0.500 & 0.387 & 0.024 & $\hat{\mathrm{Y}}=0.46$ & 0.064 \\
Total weight of by-products & 8.456 & 8.802 & 8.381 & 8.314 & 0.129 & $\hat{\mathrm{Y}}=8.48$ & 0.454 \\
\hline
\end{tabular}

Regression equation

Rumen $\quad{ }^{1} \hat{Y}=0.775+0.0030 \mathrm{X}-0.000033 \mathrm{X}^{2}$

$\mathrm{SEM}=$ standard error of the mean; $\mathrm{Eq}=$ equation; $\mathrm{X}=$ level of cassava wastewater dregs in replacement for corn.

There was no effect $(P>0.05)$ of the diets on the weight of the "Panelada", yields of viscera, byproducts, "Buchada" and yours relations with BWS and EBW (Table 8).

There was a significance $(P<0.05)$ of the weight of "Buchada" with the substitution of corn by cassava wastewater dregs (Table 8), with quadratic behaviour and a maximum point at 6.25 $\mathrm{kg}$ of the $49.11 \%$ replacement level. This result of the weight of "Buchada" corroborates the weight of the rumen (Table 7), which also showed a quadratic behaviour, possibly influenced by NDFI. 
Table 8. Weights and yields the empty viscera, by-products and "Buchada" and "Panelada" of lambs fed with cassava wastewater dregs in replacement for corn.

\begin{tabular}{|c|c|c|c|c|c|c|c|}
\hline \multirow{2}{*}{ Variables } & \multicolumn{5}{|c|}{ Replacement levels (\%) } & \multirow{2}{*}{$\mathrm{Eq}$} & \multirow[b]{2}{*}{ P-value } \\
\hline & 0 & 33 & 66 & 100 & SEM & & \\
\hline Vicera/BWS (\%) & 6.07 & 6.24 & 5.91 & 5.94 & 0.086 & $\hat{\mathrm{Y}}=6.04$ & 0.510 \\
\hline Vicera/EBW (\%) & 6.98 & 7.06 & 6.75 & 6.85 & 0.099 & $\hat{\mathrm{Y}}=6.91$ & 0.710 \\
\hline By-products/BWS (\%) & 23.16 & 22.27 & 22.17 & 22.00 & 0.240 & $\hat{\mathrm{Y}}=22.40$ & 0.245 \\
\hline By-products/EBW (\%) & 26.58 & 25.17 & 25.28 & 25.37 & 0.256 & $\hat{\mathrm{Y}}=25.61$ & 0.059 \\
\hline Buchada $(\mathrm{kg})^{\mathrm{a}}$ & 5.37 & 6.01 & 5.60 & 5.47 & 0.096 & 1 & 0.041 \\
\hline Buchada/BWS (\%) & 14.67 & 15.22 & 14.85 & 14.48 & 0.131 & $\hat{\mathrm{Y}}=14.81$ & 0.235 \\
\hline Buchada/EBW (\%) & 16.84 & 17.21 & 16.94 & 16.71 & 0.144 & $\hat{\mathrm{Y}}=16.92$ & 0.662 \\
\hline Panelada $(\mathrm{kg})^{\mathrm{b}}$ & 8.56 & 9.30 & 8.75 & 8.65 & 0.126 & $\hat{\mathrm{Y}}=8.81$ & 0.080 \\
\hline Panelada/ BWS (\%) & 23.43 & 23.56 & 23.19 & 22.89 & 0.151 & $\hat{\mathrm{Y}}=23.27$ & 0.398 \\
\hline \multirow[t]{2}{*}{ Panelada/ EBW (\%) } & 26.90 & 26.63 & 26.45 & 26.40 & 0.167 & $\hat{\mathrm{Y}}=26.60$ & 0.674 \\
\hline & \multicolumn{5}{|c|}{ Regression equation } & & \\
\hline Buchada $(\mathrm{kg})^{\mathrm{a}}$ & ${ }^{1} \hat{Y}=5$. & 0.0167 & 00017 & & & & \\
\hline
\end{tabular}

BWS = body weight at slaughter; EBW = empty body weight.

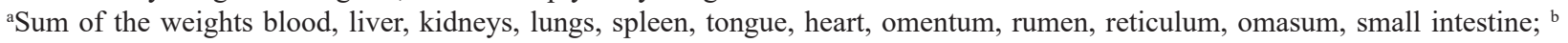
Buchada + head + feet; SEM = standard error of the mean; Eq = equation; $X=$ level of cassava wastewater dregs in replacement for corn.

Similar values for buchada and panelada yields were found by Clementino et al. (2007), with 15\% and $24.06 \%$ respectively while Medeiros et al. (2008) found values of 15.26 and $18.26 \%$ of buchada yield compared to BWS and EBW respectively. According Pompeu et al. (2013) the processing of these organs should be performed in order to add value to the product, increasing revenues of sheep breeding so it becomes a profitable activity, especially for small farmers.

\section{Conclusion}

Cassava wastewater dregs can be used as an alternative food in the diet of feedlot sheep because they do not affect carcass characteristics and noncarcass components.

\section{Acknowledgements}

The authors thank CNPq/INSA (National Counsel of Technological and Scientific
Development and National Institute for the SemiArid) for funding the research.

\section{References}

ALMEIDA, S. R. M.; SILVA, A. M.; LIMA, J. P.; ALMEIDA, A. M. M.; ZACHARIASET, F. Avaliação do potencial nutritivo da manipueira na dieta de ovinos deslanados. Revista Brasileira de Agroecologia, Recife, v. 4, n. 2, p. 1434-1438, 2009.

ALVES, D. D.; ARAÚJO, L. M.; MONTEIRO, H. C. F.; LEONEL, F. P.; SILVA, F. V.; SIMÕES, D. A.; GONÇALVES, W. C.; BRANT, L. M. S. Características de carcaça, componentes não-carcaça e morfometria em ovinos submetidos a diferentes estratégias de suplementação. Semina: Ciências Agrárias, Londrina, v. 34, n. 6, p. 3093-3104, 2013.

AMORIM, G. L.; BATISTA, A. M. V.; CARVALHO, F. F.; GUIM, A.; CABRAL, A. M. D.; MORAES, A. C. A. Substituição do milho por casca de soja: consumo, rendimentos e características de carcaça e rendimento de buchada de caprinos. Revista Acta Scientiarium. Animal Sciences, Maringá, v. 30, n. 1, p. 41-49, 2008.

BARROS, M. C. C.; MARQUES, J. A.; SILVA, R. R.; SILVA, F. F.; COSTA, L. T.; GUIMARÃES, G. S.; SILVA, 
L. L.; GUSMÃO, J. J. N. Viabilidade econômica do uso da glicerina bruta em dietas para cordeiros terminados em confinamento. Semina: Ciências Agrárias, Londrina, v. 36, n. 1, p. 443-452, 2015.

BOCCARD, R.; DUMONT, B. L. Etude de la production de la viande chez les ovins. II variation de l'importance relative des differents régions corporelles de l'agneau de boucherie. Annales de Zootechnie, Jouy-en-Josas, v. 9, n. 4, p. 355-365, 1960.

BRASIL. Ministério da Agricultura. Regulamento da inspeção industrial e sanitária de produtos de origem animal. Ministério da Agricultura, Brasília, 1997. p. 3032.

CEZAR, M. F.; SOUSA, W. H. Carcaças ovinas e caprinas: obtenção, avaliação e classificação. Uberaba: Agropecuária Tropical, 2007. 147 p.

CEZAR, M. F.; SOUSA, W. H. Proposta de avaliação e classificação de carcaças de ovinos deslanados e caprinos. Tecnologia \& Ciência Agropecuária, João Pessoa, v. 4, n. 4, p. 41-51, 2010.

CLEMENTINO, R. H.; SOUSA, W. H.; MEDEIROS, A. N.; CUNHA, M. G. G.; GONZAGA NETO, S.; CARVALHO, F. F. R.; CAVALCANTE, M. A. Influência dos níveis de concentrado sobre os cortes comerciais, os constituintes não carcaça e os componentes da perna de cordeiro confinados. Revista Brasileira de Zootecnia, Viçosa, MG, v. 36, n. 3, p. 681-688, 2007.

COSTA, R. G.; LIMA, A. G. V. O.; OLIVEIRA, C. F. S.; AZEVEDO, P. S.; MEDEIROS, A. N. Utilização de diferentes metodologias para determinação da área de olho de lombo em ovinos. Archivos de Zootecnia, Córdoba, v. 61, n. 223, p. 615-618, 2012.

CUNHA, E. A.; BUENO, M. S.; SANTOS, L. E. Características de carcaças de cordeiros de raças de corte criados intensivamente. 2002. Disponível em: $<$ http://www.cico.rj.gov.br>. Acesso em: 21 fev. 2016.

DETMANN, E.; SOUZA, M. A.; VALADARES FILHO, S. C.; QUEIROZ, A. C.; BERCHIELLI, T. T.; SALIBA, E. O. S.; CABRAL, L. S.; PINA, D. S.; LADEIRA, M. M.; AZEVEDO, J. A. G. (Ed.). Métodos para análise de alimentos. Visconde do Rio Branco: Suprema, 2012. 214 p.

FARIA, P. B.; SILVA, N. J.; RODRIGUES, A. Q.; TEIXEIRA, P. D.; MELO, L. Q.; COSTA, S. F.; ROCHA, M. F. M.; PEREIRA, A. A. Processamento da casca de mandioca na alimentação de ovinos: desempenho, características de carcaça, morfologia ruminal e eficiência econômica. Revista Brasileira de Zootecnia, Viçosa, MG, v. 40, n. 12, p. 2929-2937, 2011.
FERREIRA, M. S. Avaliação bromatológica dos resíduos da industrialização da mandioca e seu aproveitamento em ração para animais ruminantes. Revista Brasileira de Agropecuária Sustentável, Viçosa, MG, v. 3, n. 1, p. 105109, 2013.

FURUSHO-GARCIA, I. F.; COSTA, T. I. R.; ALMEIDA, A. K.; PEREIRA, I. G.; ALVARENGA, F. A. P.; LIMA, N. L. L. Performance and carcass characteristics of Santa Inês pure lambs and crosses with Dorper e Texel at different management systems. Revista Brasileira de Zootecnia, Viçosa, MG, v. 39, n. 6, p. 1313-1321, 2010.

FURUSHO-GARCIA, I. F.; PEREZ, J. R. O.; BONAGURIO, S.; LIMA, A. L.; QUINTÃO, F. A. Estudos dos cortes de carcaça de cordeiros Santa Inês puros e cruzas Santa Inês com Texel, Ile de France e Bergamácia. Revista Brasileira de Zootecnia, Viçosa, MG, v. 33, n. 2, p. 453-462, 2004.

GERRARD, D. E.; GRANT, A. L. Principles of animal growth and development. Revised Printing. Purdue University: Kendall/Hunt Publishing Company, 2006. $264 \mathrm{p}$.

HALL, M. B. Calculation of non-structural carbohydrate content of feeds that contain non-protein nitrogen. Gainesville: University of Florida, 2000. A-25 p. (Bulletin, 339).

HASHIMOTO, J. H.; OSÓRIO, J. C. S.; OSÓRIO, M. T. M.; BONACINAM, S.; LEHMEN, R. I.; PEDROSO, C. E. S. Qualidade de carcaça, desenvolvimento regional e tecidual de cordeiros terminados em três sistemas. Revista Brasileira de Zootecnia, Viçosa, MG, v. 41, n. 2, p. 438-448, 2012.

HOPKINS, D. L.; TOOHEY, E. S.; LAMB, T. A.; KERR, M. J.; VAN DE VEN, R.; REFSHAUGE, G. Explaining the variation in the shear force of lamb meat using sarcomere length, the rate of rigor onset and $\mathrm{pH}$. Meat Science, Amsterdam, v. 88, n. 4, p. 794-796, 2011.

MARTINS, R. R. C.; OLIVEIRA, N. M.; OSÓRIO, J. C. S.; OSÓRIO, M. T. M. Peso vivo ao abate como indicador do peso e das características quantitativas e qualitativas das carcaças em ovinos jovens da raça Ideal. Bagé: Empresa Brasileira de Pesquisa Agropecuária, 2000. 29 p.

MCALLISTER, T. A.; PHILliPE, R. C.; RODE, L. M.; CHENG, K. J. Effect of the protein matrix on the digestion of cereal grains by ruminal microorganisms. Journal of Animal Science, Champaing, v. 71, n. 1, p. 205-212, 1993

MEDEIROS, G. R.; CARVALHO, F. F. R.; FERREIRA, M. A.; ALVES, K. S.; MATTOS, C. W.; SARAIVA, T. A.; 
NASCIMENTO, J. F. Efeito dos níveis de concentrado sobre os componentes não-carcaça de ovinos Morada Nova em confinamento. Revista Brasileira de Zootecnia, Viçosa, MG, v. 37, n. 6, p. 1063-1071, 2008.

NATIONAL RESEARCH COUNCIL - NRC. Nutrient requeriments of small ruminants: sheep, goats, cervids, and new world camelids. Washington D.C.: National Academy Press, 2007. 362 p.

POMPEU, R. C. F. F.; BESERRA, L. T.; CÂNDIDO, M. J. D.; BOMFIM, M. A. D.; VIEIRA, M. M. M.; ANDRADE, R. R. Características da carcaça e dos componentes não-carcaça de ovinos alimentados com dietas contendo casca de mamona. Revista Brasileira de Saúde e Produção Animal, Salvador, v. 14, n. 3, p. 490507, 2013.

REGO, F. C. A.; FRANÇOZO, M. C.; LUDOVICO, A.; LIMA, L. D.; LOPES, F. G.; BELAN, L.; SANTOS, M. D.; ZUNDT, M.; CUNHA FILHO, L. F. C.; CONSTANTINO, C. Development, economic viability and attributes of lamb carcass from confined animals fed on different amounts of crude glycerin. Semina: Ciências Agrárias, Londrina, v. 36, n. 5, p. 3445-3454, 2015.

SANTOS FILHO, H. B.; VÉRAS, R. M. L.; FERREIRA, M. A. F.; SILVA, J. L.; VASCONCELOS, G. A.; SOARES, L. F. P.; CARDOSO, D. B. Liquid residue of cassava as a replacement for corn in the diets of sheep. Tropical Animal Health Prodution, Dordrecht, v. 47, n. 6, p. 1083-1088, 2015.

STATISTICAL ANALYSIS SYSTEM INSTITUTE SAS. User's Guide, Version 9.0. Cary: SAS Institute Inc., 2002.

SILVA SOBRINHO, A. G.; GONZAGA NETO, S. Produção de carne caprina e cortes da carcaça. 2001. 13 p. Disponível em: https://www.google.com.br/\#q=Pr odu $\% \mathrm{C} 3 \% \mathrm{~A} 7 \% \mathrm{C} 3 \% \mathrm{~A} 3 \mathrm{o}+$ de + carne + caprina $+\mathrm{e}+$ cortes + $\mathrm{da}+$ carca\%C3\%A7a.pdf $>$. Acesso em: 29 set. 2015.

SILVA SOBRINHO, A. G.; PURCHAS, R. W.; KADIM, I. T.; YAMAMOTO, S. M. Características de qualidade da carne de ovinos de diferentes genótipos e idades ao abate. Revista Brasileira de Zootecnia, Viçosa, MG, v. 34, n. 3, p. 1070-1078, 2005.

SNIFFEN, C. J.; O'CONNOR, J. D.; VAN SOEST, P. J.; FOX, D. G.; RUSSEL, J. B. A net carbohydrate and protein system for evaluating cattle diets II. Carbohydrate and protein availability. Journal of Animal Science, Champaing, v. 70, n. 11, p. 3562-3577, 1992.
SOUZA, S. O.; OLIVEIRA, L. C.; CAVAGIS, A. D. M.; BOTERO, W. G. Cyanogenic residues: Environmental impacts, complexation with humic substances, and possible application as biofertilizer. Water, Air, Soil \& Soil Pollution, Switzerland, v. 225, n. 12, p. 2223-2227, 2014.

URANO, F. S.; PIRES, A. V.; SUSIN, I.; MENDES, C. Q.; ROGRIGUES, G. H.; ARAUJO, R. C.; MATTOS, W. R. S. Desempenho e características da carcaça de cordeiros confinados alimentados com grão de soja. Pesquisa Agropecuária Brasileira, Brasília, v. 41, n. 1, p. 1525-1530, 2006.

URBANO, S. A.; FERREIRA, M. A.; VÉRAS, R. M. L.; AZEVEDO, P. S.; SANTOS FILHO, H. B.; VASCONCELOS, G. A.; OLIVEIRA, J. P. F. Características de carcaça e composição tecidual de ovinos Santa Inês alimentados com manipueira. Agrária, Recife, v. 10, n. 3, p. 466-472, 2015.

VAN SOEST, P. J. Nutritional ecology of the ruminant. $2^{\text {th }}$ ed. London: Constock Publishing Associates, 1994. $476 \mathrm{p}$.

VASCONCELOS, G. A. Borra de manipueira em substituição ao milho na dieta de cordeiros. 2013. Dissertação (Mestrado em Zootecnia) - Universidade Federal Rural de Pernambuco, Recife.

WEISS, W. Energy prediction equations for ruminant feeds. In: CORNELL NUTRITION CONFERENCE FOR FEED MANUFACTURERS, 61., 1999, Ithaca. Proceedings... Ithaca: Cornell University, 1999. p. 176185.

XENOFONTE, A. R. B.; CARVALHO, F. F. R.; BATISTA, A. M. V.; MEDEIROS, G. R. Características de carcaça de ovinos em crescimento alimentados com rações contendo farelo de babaçu. Revista Brasileira de Zootecnia. Viçosa, MG, v. 38, n. 2, p. 392-398, 2009.

ZEOULA, L. M.; MARTINS, A. S.; PRADO, I. N.; ALCALDE, C. R.; BRANCO, A. F.; SANTOS, G. T. Solubilidade e degradabilidade ruminal do amido de diferentes alimentos. Revista Brasileira de Zootecnia, Viçosa, MG, v. 28, n. 5, p. 898-905, 1999.

ZUNDT, M.; MACEDO, F. A. F.; MARTINS, E. N.; MEXIA, A. A.; NIETO, L. M.; YAMAMOTO, S. M.; MACEDO, R. M. G. Características de carcaça de cordeiros terminados em confinamento, com dietas contendo diferentes níveis proteicos. Ciência Rural, Santa Maria, v. 33, n. 3, p. 565-571, 2003. 